\title{
EXPRESSION OF CADHERIN GENE IN Bacillus thuringiensis Cry1A TOXIN RESISTANT AND SUSCEPTIBLE STRAINS OF Tirathaba mundella
}

\author{
CALVIN TAN ZHE KHAI*; PATRICIA KING JIE HUNG**; SU CHONG MING**; HO KOK LIAN* \\ and LAU WEI HONG¥
}

\begin{abstract}
Bacillus thuringiensis (Bt.) insecticide has since been used as an essential insecticide in commercial oil palm plantations to manage insect pests. Resistance against Bt. toxins has been reported in many pest insects and threatening the effectiveness of $\mathrm{Bt}$. insecticide. However, the insecticide resistance capability of Tirathaba mundella (T. mundella) was not well documented due to its finite molecular data. In this study, the potential of insecticide resistance development in $\mathrm{T}$. mundella was examined through bioassay and cadherin gene expression analysis. Cadherin gene which often associated with the resistance against Bt. toxin was amplified and its relative expressions were studied using quantitative polymerase chain reactions. T. mundella collected from the plantations with frequent exposure to Bt. insecticide was found to develop resistance to Cry1A with a significantly lower cadherin gene transcript level and lower mortality compared to the susceptible strain. Besides, a relatively lower level of cadherin gene expression was found in the early development stages of the resistant strain. The adaptation of larvae to the Bt. insecticide may be caused by the irregular application of insecticide in the field.
\end{abstract}

Keywords: Bt. toxin, cadherin, expression profile, resistance, Tirathaba mundella.

Received: 16 October 2019; Accepted: 26 July 2020; Published online: 7 October 2020.

\section{INTRODUCTION}

Over the past decades, Bacillus thuringiensis (Bt.) which produce species-specific Cry toxin has been broadly applied to control pest outbreak and incorporated with plants to develop transgenic crops (Jouzani et al., 2017). The Cry toxins are activated by the digestive protease in the insect midgut after ingested (Vachon et al., 2012). The activated

\footnotetext{
* Institut Ekosains Borneo,

Faculty of Agriculture and Food Sciences,

Universiti Putra Malaysia,

P.O. Box 396, Nyabau Road,

97008 Bintulu, Sarawak, Malaysia.

E-mail: patricia@upm.edu.my

** Faculty of Medicine and Health Sciences, Universiti Putra Malaysia,

43400 UPM Serdang, Selangor, Malaysia.

‡ Plant Protection, Faculty of Agriculture, University Putra Malaysia,

43400 UPM Serdang, Selangor, Malaysia.
}

toxins will then bind to the protein receptors which include cadherin, aminopeptidase- $\mathrm{N}$ and alkalinephosphatase on the brush-border membrane (Pacheco et al., 2009). The binding facilitates oligomer formation and integration of toxin into the midgut membrane. The insertion resulting in pore formation, cell lysis and cause the death of the insect (Sanahuja et al., 2011).

The prevalence of Bt. insecticide to control agricultural pests has found to threaten its efficacy due to the development of resistance to $B t$. toxins. The downregulation of cadherin gene has been discovered to contribute to the resistance mechanism (Tabashnik, 1994). Cadherin is a protein responsible for the calcium-dependent cell adhesion and cell sorting mechanism. It was reported as one of the binding receptors of Cry toxin in the midgut of Lepidopteran, Coleopteran and Dipteran insects. A mutation in the cadherin gene was found to be associated with the resistance to the $B t$. toxin (Bel and Escriche, 2006). In the resistant strain of Pectinophora 
gossypiella, a deletion mutation of cadherin gene was discovered to confer resistance to Cry1Ac toxin (Wang et al., 2018).

$B t$. insecticide has since been adopted in the oil palm industry to control the infestation of Tirathaba mundella (T. mundella) (Lepidoptera: Pyralidae). T. mundella is a major pest that causes severe harms to oil palm, particularly those planted on peatland (Masijan et al., 2015; Yaakop and Shafariza, 2015). The larval stage makes an opening on the immature fruit bunch and boring holes into the mesocarp. The infestation damaging the male and female inflorescence as well, resulting in the malformed or stunted developed bunches (Alouw et al., 2005). The weight and quality of the bunches may greatly affect by the infestation and the damaged fruit bunches may fall prematurely (Yaakop and Shafariza, 2015). An uncontrolled infestation of T. mundella could cause $50 \%$ reduction in fresh fruit bunch (FFB) production (Su et al., 2016). Saharul et al. (2017) reported an area of more than 47700 ha of oil palm plantation in Malaysia was affected by the infestation. Bt. var. kurstaki has been reported as an effective bioinsecticide to control the infestation (Huan, 2012; Prasetyo et al., 2018; Saharul et al., 2017). Huan (2012) reported that six continuous fortnightly sprays of Bt. var. kurstaki over a three-month period were able to bring down the infestation to less than $15 \%$ in a plantation with $50 \%$ of infested bunches. Nevertheless, the potential of T. mundella to develop $B t$. insecticide resistance under an inconsistent schedule of field spraying practices has not been well evaluated. Besides, the lack of molecular data for T. mundella has greatly constrained the study of its resistance mechanism.

In the current study, the cadherin gene of $T$. mundella was amplified and its expression was examined on the insects from plantations with different pest management practices. The objectives were to study the development of resistant strains after a long-term of irregular insecticide exposure and evaluate its association with the gene transcript level at different developmental stages. The findings of this study could provide insight into the molecular mechanism of the resistance to Cry1A toxin.

\section{MATERIALS AND METHODS}

\section{Sample Collection}

Tirathaba mundella specimens were collected from two peatland oil palm estates with similar cultivation practices but different pest control management: a) Sabaju Estate (KM 31, Bakun Road, Sarawak, Malaysia) was frequently applied with Dipel, a commercial formulation of Bt. var. kurstaki with Cry1A toxin when the infestation of T. mundella was reported in the area (Figure 1). The insecticide was applied to the male and female inflorescences and fruit bunches of the infested palm using the manufacturer's recommended dosage. b) Tinbarap Estate (KM 22, Miri - Bintulu Road, Sarawak) was not exposed to any insecticide over a one-year period when the larvae were collected due to budget constraints (Figure 1). Although the two estates are maintained with different pest management methods, the land selection, harvesting and environmental management of both estates are carried out in accordance with the same protocol. Sabaju and Tinbarap Estates are established in mixed peat swamp forest areas and planted with oil palms for more than 10 years old. The soil series of Sabaju and Tinbarap estates are Sabaju and Gondang soil series respectively $(\mathrm{Su}, 2019)$.

Infested fruit bunches with fresh reddish-brown frass of T. mundella were carefully cut down and chopped into small pieces. A number of 200 larvae

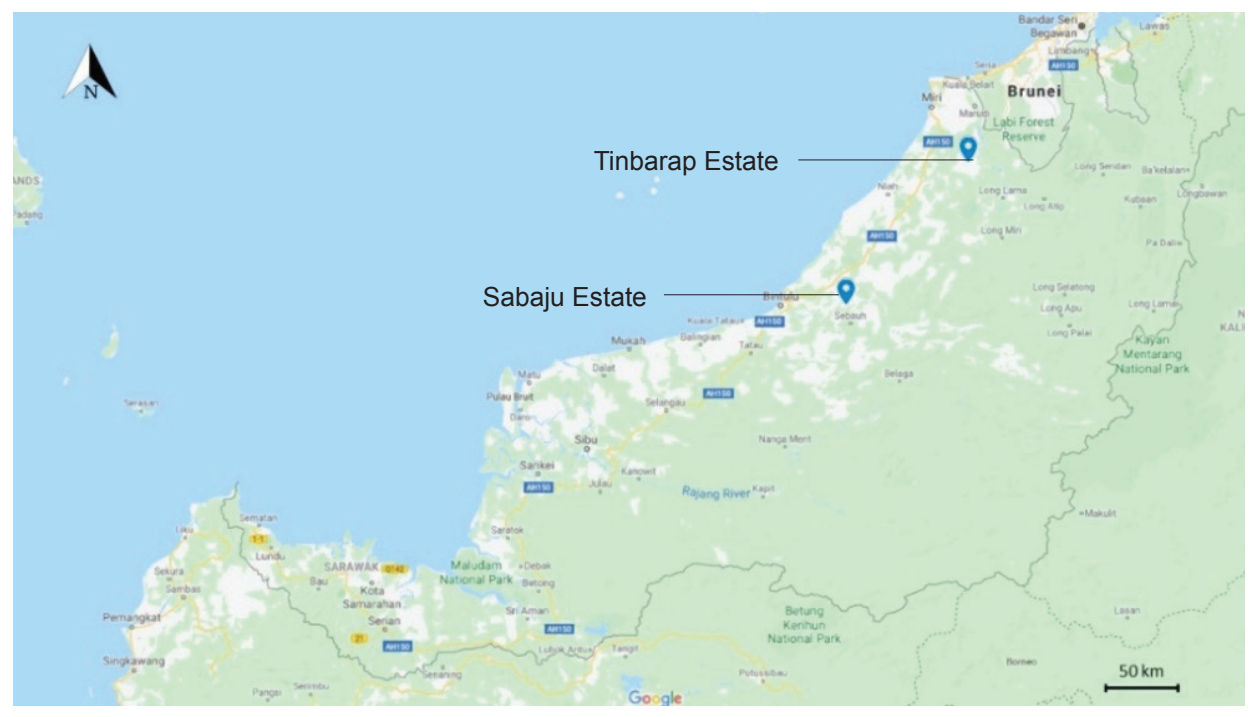

Figure 1. Map of Sabaju Estate and Tinbarap Estate, Sarawak, Malaysia. 
of different instars were screened from the chopped fruit bunches. Collected larvae were supplied with an artificial diet developed by Universiti Putra Malaysia Bintulu Campus (UPMKB) (Su, 2019). The diet contains essential nutrients required for the growth of larvae. Sucrose and casein were included in the diet ingredient as the source of carbohydrate and protein, respectively. Wesson salt was added as mineral sources while vitamin sources were provided by Vanderzant vitamin and ascorbic acid (Hervet et al., 2016). Palm male inflorescence was added as phagostimulant to facilitate the adaptation of larvae toward the change of environment and food source (Morton, 1981). The insect rearing environment was maintained at $25^{\circ} \mathrm{C}-27^{\circ} \mathrm{C}$ and 12 hr light: 12 hr dark photoperiod (Su et al., 2019).

\section{Bioassay}

For the bioassay, $157 \mathrm{mg} \mathrm{ml}^{-1}$ of Cry1A toxin was prepared from the UPMKB insecticide collection following the suggested application amount. The toxin was incorporated in the artificial diet and sprayed on the diet surface. The sprayed diet was allowed to air dry before the placement into a rearing container. Cry1A toxin was replaced with sterile distilled water for the negative control. Healthy fourth instar larvae of $T$. mundella were released into the rearing container after starving for $12 \mathrm{hr}$ to promote diet consumption. The bioassay was conducted in 15 replicates with one larva in each rearing container. Larval mortality was recorded after $96 \mathrm{hr}$ of exposure to a toxin treated diet. The insects were identified as alive if they respond to touch (Yang et al., 2009). The insects were transferred to a new rearing container with a normal diet after five days of toxin exposure to complete their normal development (Xu et al., 2005).

\section{Total Ribonucleic Acid (RNA) Isolation and} Complementary DNA (cDNA) Synthesis

Two sets of insects were collected for ribonucleic acid (RNA) isolation: a) fourth instar T. mundella after exposing to Cry1A toxin $(0,2,8,24$ and 48 $\mathrm{hr}$ ), and b) different developmental stages of $T$. mundella under normal rearing conditions (fourth to seventh instar larvae and pupae) (Ayra-Pardo et al., 2015). Whole bodies of insects were first chopped into smaller pieces with a scalpel to enhance the grinding process. Total RNA of T. mundella was extracted by using Tissue Total RNA Mini Kit (Favorgen, Ping Tung, Taiwan) according to the manufacturer's instructions. RNase Quiet (Nacalai Tesque, Kyoto, Japan) was treated on all apparatus to avoid RNase contamination. The extracted RNA was stored immediately at $-80^{\circ} \mathrm{C}$. Quantification of extracted RNA was performed using $1 \%$ TAE agarose gel electrophoresis. The extract was treated with DNase (Toyobo, Tokyo, Japan) to avoid DNA contamination. First strand complimentary DNA (cDNA) was synthesised using Revertra Ace qPCR RT Master Mix (Toyobo, Osaka, Japan) following manufacturer's protocols. Real time minus (RTminus) control was reverse transcribed together with the specimens with the absence of RT enzymes as the negative control (Raymaekers et al., 2009). The cDNA was kept at $-20^{\circ} \mathrm{C}$ until further analysis.

\section{Cadherin Gene Amplification}

In the absence of gene sequence data for T. mundella, primers designed for the amplification of cadherin gene fragment of Chilo suppressalis (JQ747493) were selected to amplify the cadherin gene of T. mundella (Table 1). The polymerase chain reaction (PCR) reaction was performed using $\mathrm{XP}$ Cycler (Bioer, Tokyo, Japan) under the condition of $94^{\circ} \mathrm{C}$ for $5 \mathrm{~min}$, followed by 30 cycles of denaturation at $94^{\circ} \mathrm{C}$ for $1 \mathrm{~min}$, annealing at $44^{\circ} \mathrm{C}$ for $2 \mathrm{~min}$ and elongation at $72^{\circ} \mathrm{C}$ for $1 \mathrm{~min}$. The reaction ended with the final elongation at $72^{\circ} \mathrm{C}$ for $10 \mathrm{~min}$.

The $\beta$-actin gene sequences of closely related Lepidoptera species (Plutella xylostella, NM_001309101.1; Heliothis virescens, AF368030.1; Helicoverpa armigera, HM629441.1; Bombyx mori, NM_001126254.1; Manduca sexta, L13764.1) were collected from National Center for Biotechnology Information (NCBI) database and aligned with Mega version 7. Gene specific primers were designed from the conserved region using PriFi (https://services.birc.au.dk/prifi/) (Table 1). The amplification of $\beta$-actin region was performed under the same PCR protocol with the annealing temperature of $54^{\circ} \mathrm{C}$.

The PCR product was visualised using a $1 \%$ agarose gel electrophoresis. The amplified fragment was purified with QIAquick Gel Extraction Kit (Qiagen, Hilden, Germany) according to the manufacturer's protocol and sequenced by the Apical Scientific Sdn. Bhd. The amplified cadherin fragment of $T$. mundella was aligned with other Lepidopteran cadherin sequences to construct a maximum likelihood tree using Mega version 7 with 1000 replicates bootstrap support. Based on the sequences obtained, primers encoding for cadherin and $\beta$-actin gene with an amplicon length of $120 \mathrm{bp}$ and $134 \mathrm{bp}$ respectively were designed by using

TABLE 1. PRIMER SEQUENCES FOR THE AMPLIFICATION OF TARGETED GENES

\begin{tabular}{lll}
\hline Gene & \multicolumn{2}{c}{ Primer sequence } \\
\hline CadF & Sense & 5'-GACGGAACTTCAGCAAACAAC-3' \\
CadR & Antisense & 5'-CTCGGAATTATCAGTGGCAATG-3' \\
ActinF & Sense & 5'-ATGTGCAAGGCCGGTTTCGC-3' \\
ActinR & Antisense & 5'-CTCGGTGAGGATCTTCATGAGG-3' \\
\hline
\end{tabular}


NCBI Primer-BLAST (https://www.ncbi.nlm. nih.gov/tools/primer-blast/) for gene expression analysis (Table 2).

TABLE 2. PRIMER SEQUENCES FOR QUANTITATIVE POLYMERASE CHAIN REACTION (qPCR)

\begin{tabular}{lll}
\hline Gene & & Primer sequence \\
\hline TmACTF & Sense & 5'-GTCGTACCACCGGTATCG-3' \\
TmACTR & Antisense & 5'-CATGAGGTAGTCGGTCAAGTC-3' \\
TmCADF & Sense & 5'-GCCGTCAGGCGCTCTATTTA-3' \\
TmCADR & Antisense & 5'-TCGCAGCAATACACACCACA-3' \\
\hline
\end{tabular}

Quantitative Reverse Transcription Polymerase Chain Reaction Analysis of Cadherin Gene

Quantitative polymerase chain reaction (qPCR) was performed using Bio-rad Mini Opticon PCR system (Bio-Rad, California, USA) to investigate the cadherin gene temporal expression pattern of fourth to seventh instar larvae and pupae of T. mundella as well as the relative gene transcript level of larvae after feeding on a toxin treated diet for $0,2,8,24$ and $48 \mathrm{hr}$. The qPCR reaction contained $4 \mu \mathrm{l}$ of the ThunderBird SYBR qPCR Mix (Toyobo, Osaka, Japan), 10 pmol of forward and reverse primer, $1 \mu \mathrm{l}$ of the first strand cDNA template (150 ng $\mu l^{-1}$ ) and double distilled water $\left(\mathrm{ddH}_{2} \mathrm{O}\right)$ to the total reaction volume of $20 \mu \mathrm{l}$. The three steps qPCR program was performed as follows: 1 min of initial denaturation at $95^{\circ} \mathrm{C}$ followed by 40 cycles of denaturation at $95^{\circ} \mathrm{C}$ for $15 \mathrm{~s}$, annealing for $30 \mathrm{~s}$ and $1 \mathrm{~min}$ extension at $60^{\circ} \mathrm{C}$. The annealing temperature for cadherin and $\beta$-actin primer were $53^{\circ} \mathrm{C}$ and $59^{\circ} \mathrm{C}$, respectively. The samples were heated up to $95^{\circ} \mathrm{C}$ for melting curve analysis. Water and RT-minus control were served as a negative control to detect primer-dimers and genomic DNA contamination (Ren et al., 2013). Only the amplification with single peak in melting curve analysis and amplification efficiency of $95 \%-100 \%$ was selected for gene expression analysis (Guo et al., 2015).

\section{Data Analysis}

The relative abundance of the cadherin gene was normalised to the reference gene $\beta$-actin and expressed using the relative expression method $\left(2^{-\Delta \Delta C t}\right)$. Cadherin expression in each development stage was normalised against the expression of the pupae from Tinbarap Estate. To ensure the validity of the data, three technical replicates and three biological replicates were tested for each treatment (Yang et al., 2012). Gene expression and bioassay data were statically analysed by using SAS software (SAS version 9.4). The mean difference of the gene expression at different development stages and during bioassay were determined using Tukey's HSD $(p<0.05)$. The significant difference in gene expression, mortality and adult emergence rate between the sampling sites were analysed with independent-sample $\mathrm{t}$ test.

\section{RESULTS}

\section{Resistance Gene}

A fragment of $773 \mathrm{bp}$ of gene sequence was amplified from T. mundella cDNA template. Identical sequence was amplified from the sample collected from Sabaju and Tinbarap Estates. The evolutionary of the cadherin gene was evaluated with seven Lepidoptera sequences from NCBI database. $T$. mundella gene sequence showed a genetic distance range of 0.722 to 0.864 compared to the other cadherin gene sequences (Ostrinia furnacalis, EU022587.1; P. xylostella, NM_001305494.1; Pectinophora gossypiella, KJ480752.1; M. sexta, AY094541.1; B. mori, AB026260.1; Spodoptera exigua, KC907716.1; C. suppressalis, JQ747493.2) (Table 3 and Figure 2).

TABLE 3. ESTIMATES OF EVOLUTIONARY DIVERGENCE BETWEEN CADHERIN SEQUENCES

\begin{tabular}{|c|c|c|c|c|c|c|c|c|c|}
\hline No. & Sample & 1 & 2 & 3 & 4 & 5 & 6 & 7 & 8 \\
\hline 1 & Ostrinia furnacalis & & & & & & & & \\
\hline 2 & Plutella xylostella & 0.412 & & & & & & & \\
\hline 3 & Pectinophora gossupiella & 0.493 & 0.517 & & & & & & \\
\hline 4 & Manduca sexta & 0.471 & 0.495 & 0.408 & & & & & \\
\hline 5 & Bombyx mori & 0.472 & 0.496 & 0.497 & 0.475 & & & & \\
\hline 6 & Spodoptera exigua & 0.551 & 0.575 & 0.576 & 0.554 & 0.435 & & & \\
\hline 7 & Tirathaba mundella & 0.839 & 0.863 & 0.864 & 0.842 & 0.723 & 0.722 & & \\
\hline 8 & Chilo suppressalis & 1.007 & 1.031 & 1.032 & 1.010 & 0.891 & 0.890 & 0.896 & \\
\hline
\end{tabular}

Source: Kumar et al. (2016).

Note: The number of base substitutions per site from between sequences are shown. Analyses were conducted using the Tamura-Nei model (Tamura and Nei, 1993). The analysis involved eight nucleotide sequences. Codon positions included were $1^{\text {st }}+2^{\text {nd }}+3^{\text {rd }}+$ noncoding. All positions containing gaps and missing data were eliminated. There was a total of 747 positions in the final dataset. Evolutionary analyses were conducted in MEGA7. 


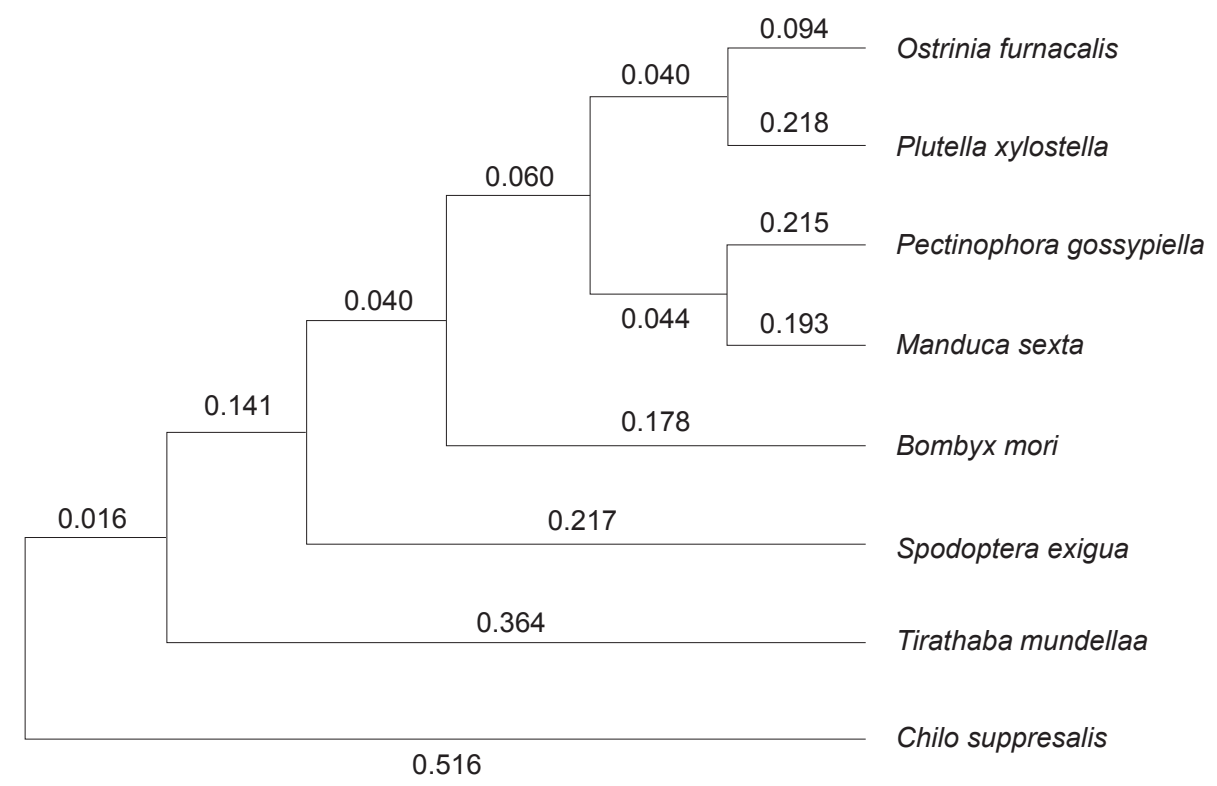

Figure 2. Molecular phylogenetic analysis by maximum likelihood method. The evolutionary history was inferred by using the Maximum Likelihood method based on the Tamura-Nei model (Tamura and Nei, 1993). The tree with the highest log likelihood (-5854.7770) is shown. Initial tree(s) for the heuristic search were obtained automatically by applying Neighbour-Join and BioNJ algorithms to a matrix of pairwise distances estimated using the Maximum Composite Likelihood (MCL) approach, and then selecting the topology with superior log likelihood value.

\section{Mortality Assessment}

Higher mortality was recorded on the sample collected from the Tinbarap Estate compared to the Sabaju Estate after the larvae were treated with the diet containing Cry1A toxin. An increment of $80.2 \%$ of mortality was found among the Tinbarap Estate samples after exposed to Bt. insecticide. On the other hand, larvae from Sabaju Estate showed a mortality rate of $66.8 \%$ lower compared to the larvae from Tinbarap Estate and its mortality rate was not affected by the toxin after $96 \mathrm{hr}$ of exposure (Table 4). For the adult emergence rate, T. mundella from Sabaju Estate reduced significantly from $93.4 \pm 6.6 \%$ to $53.4 \pm 8.3 \%$ after toxin intake while all the larvae from Tinbarap Estate were failed to turn into moths. The insects were found dead in its larval stage or in the cocoon of its pupal stage (Table 5).

\section{Cadherin Gene Expression of Development Stages}

The expression of the cadherin gene was found to be significantly higher in the seventh instar of the Sabaju Estate sample and fourth instar of the Tinbarap Estate sample. The cadherin transcript level of Sabaju Estate sample increased from fourth to seventh instar larvae and reduced when it turns into pupae. Larvae of the seventh instar showed significantly higher cadherin expression level which increased from $0.2940 \pm 0.0620$ at sixth instar to 5.6839 \pm 0.7847 at seventh instar. In contrast, significantly higher relative abundance was observed at the fourth instar of the Tinbarap Estate sample. The relative cadherin abundance of $23.8145 \pm 2.8313$ was recorded at the fourth instar of the Tinbarap Estate sample. The expression level reduced significantly from fourth to the fifth instar and increased gradually until its pupal stage (Table 6).

Stage-specific expression analysis was performed between the sample from both estates. The cadherin expression level of the pupal stage of the Tinbarap Estate sample was set at 1 for the analysis. Significantly higher relative transcript level was found at the fourth, fifth and sixth instar larvae of the Tinbarap Estate sample. T. mundella of Sabaju Estate showed significantly higher cadherin expression at the seventh instar larvae and pupae stage compared to the specimens from the Tinbarap Estate (Table 6).

\section{Cadherin Gene Expression Under Bacillus thuringiensis (Bt.) Insecticide Exposure}

The transcript amount of cadherin of Sabaju Estate sample increased from the initial expression of $0.0016 \pm 0.0002$ to $0.3233 \pm 0.0669$ at the second hour after the intake of the toxin. The relative expression was reduced gradually to $0.0124 \pm 0.0018$ after $48 \mathrm{hr}$. An opposite trend occurred when no toxin was consumed, the relative expression of cadherin increased significantly only after $48 \mathrm{hr}$. The expression pattern of T. mundella of Tinbarap Estate was not altered by the consumption of Cry1A toxin. The relative abundance of cadherin reduced significantly from the beginning to the second hour (Table 7). 
The PCR products were electrophoresed to ensure the validity of the result, a single band of DNA was observed on the agarose gel. Melting curve analysis verified that the amplification of nonspecific products and primer-dimer were eliminated (Figure 3). This supports that the difference in gene transcript level is responsible for its abundance level at different conditions.

TABLE 4. MORTALITY RATE OF T. mundella FROM SABAJU AND TINBARAP ESTATES AFTER EXPOSED TO Bacillus thuringiensis (Bt.) INSECTICIDE FOR $96 \mathrm{HR}$

\begin{tabular}{lcc}
\hline \multirow{2}{*}{ Bioassay } & \multicolumn{2}{c}{ Mortality rate $(\%)^{*}$} \\
\cline { 2 - 3 } & Sabaju & Tinbarap \\
\hline Control & $6.6 \pm 6.6 \mathrm{a}, \mathrm{A}$ & $13.2 \pm 8.1 \mathrm{~b}, \mathrm{~A}$ \\
Treatment & $26.6 \pm 12.5 \mathrm{a}, \mathrm{B}$ & $93.4 \pm 6.6 \mathrm{a}, \mathrm{A}$ \\
\hline
\end{tabular}

Note: *Each value represents the mean \pm SE of 15 replicates of insects tested in each parameter. The significant difference between the mean values was analysed by independentsample t test. Different lowercase letters denote a significant difference in the mortality rate between the control and treatment in bioassay. Different uppercase letters indicate significant differences of mortality rate between sampling locations.

TABLE 5. ADULT EMERGENCE RATE OF T. mundella FROM SABAJU AND TINBARAP ESTATES AFTER EXPOSED TO Bacillus thuringiensis (Bt.) INSECTICIDE

\begin{tabular}{lcc}
\hline \multirow{2}{*}{ Bioassay } & \multicolumn{2}{c}{ Adult emergence (\%)* } \\
\cline { 2 - 3 } & Sabaju & Tinbarap \\
\hline Control & $93.4 \pm 6.6 \mathrm{a}, \mathrm{A}$ & $86.8 \pm 8.1 \mathrm{a}, \mathrm{A}$ \\
Treatment & $53.4 \pm 8.3 \mathrm{~b}, \mathrm{~A}$ & $0 \pm 0 \mathrm{~b}, \mathrm{~B}$ \\
\hline
\end{tabular}

Note: ${ }^{*}$ Each value represents the mean \pm SE of 15 replicates of insects tested in each parameter. The significant difference between the mean values was analysed by independentsample $t$ test. Different lowercase letters denote a significant difference in the adult emergence rate between the control and treatment in bioassay. Different uppercase letters indicate significant differences of adult emergence rate between sampling locations.

TABLE 6. QUANTIFICATION OF CADHERIN GENE EXPRESSION IN DIFFERENT DEVELOPMENT STAGES OF T. mundella FROM SABAJU AND TINBARAP ESTATES

\begin{tabular}{lcc}
\hline \multirow{2}{*}{$\begin{array}{c}\text { Development } \\
\text { stage }\end{array}$} & \multicolumn{2}{c}{ Relatively transcript level } \\
\cline { 2 - 3 } & Sabaju & Tinbarap \\
\hline $4^{\text {th }}$ instar & $0.0202 \pm 0.0053 \mathrm{c}, \mathrm{B}$ & $23.8145 \pm 2.8313 \mathrm{a}, \mathrm{A}$ \\
$5^{\text {th }}$ instar & $0.0268 \pm 0.0050 \mathrm{c}, \mathrm{B}$ & $0.3214 \pm 0.0328 \mathrm{~b}, \mathrm{~A}$ \\
$6^{\text {th }}$ instar & $0.2940 \pm 0.0620 \mathrm{c}, \mathrm{B}$ & $0.6318 \pm 0.1374 \mathrm{~b}, \mathrm{~A}$ \\
$7^{\text {th }}$ instar & $5.6839 \pm 0.7847 \mathrm{a}, \mathrm{A}$ & $0.6358 \pm 0.0987 \mathrm{~b}, \mathrm{~B}$ \\
Pupa & $3.6511 \pm 0.2040 \mathrm{~b}, \mathrm{~A}$ & $1 \pm 0 \mathrm{~b}, \mathrm{~B}$ \\
\hline
\end{tabular}

Note: *Each value represents the mean \pm SE of three technical replicates and three biological replicates of insects collected for each stage. The mean difference between the development stages was analysed by one-way ANOVA. Different lowercase letters denote a significant difference ( $p<0.05$, Tukey's HSD test) in the expression levels between the development stages. The mean difference between the sampling sites was analysed by independent-sample $t$ test. Different uppercase letters denote a significant difference in the expression levels between the sampling sites. The expression level of pupa from Tinbarap Estate was set at 1.

\section{DISCUSSION}

A gene sequence of T. mundella was amplified with the primers encoding for the cadherin receptor of C. suppressalis, a destructive rice pest commonly found in East Asia. The insect was found to develop resistance against Cry1A toxin after a long-term of $B t$. insecticide application in the field. The resistance was contributed by the mutations of the cadherin genes resulting in the downregulation and reduction in the toxin binding site (Zhang et al., 2017). The amplified gene sequence of $T$. mundella demonstrated a relatively high similarity to the cadherin gene of other Lepidoptera species including B. mori ( $\mathrm{Yu}$ et al., 2018), S. exigua (Ren et al., 2013) and C. suppresalis (Zhang et al., 2017) which were reported to confer resistance against $B t$. insecticide. This suggested that the amplified fragment of T. mundella may have common structures or functions with the cadherin protein of Lepidoptera.

Tirathaba mundella from Sabaju Estate showed no significant change in survival rate and $53.4 \%$ of the larvae were successfully turned into moth after toxin ingestion. Furthermore, lower cadherin transcript level was expressed at early developmental stages of the larvae. The resistance against Bt. insecticide was reported to associate with the low expression of the cadherin gene. Cadherin receptor which serves as the Cry toxin binding site was reduced by a decrease in the cadherin gene expression ( $\mathrm{Yu}$ et al., 2018). This allowed the larvae to remain unharmed after the ingestion of the fruit bunch sprayed with insecticide. The efficiency of insecticide application reduced as the larvae stay alive and continuously infest on the fruit bunch. The increment of cadherin expression at the seventh instar larvae and pupae stage explained the reduction in adult emergence (Table 5). The larvae were able to survive in the early developmental stages but may die during the metamorphosis process. The similar expression pattern was reported in the resistant strain of $M$. sexta (Midboe et al., 2003), P. xylostella (Yang et al., 2012) and C. suppressalis (Zhang et al., 2017) where the expression increases with the development stages of larvae and dropped in the pupae. The pattern may be associated with the role of cadherin in cell proliferation and tissue morphology, more cadherin is expressed to generate tissue at the advanced instars (Bel and Escriche, 2006; Yu et al., 2018).

In contrast, the percentage of mortality and adult emergence of T. mundella from Tinbarap Estate was greatly affected by the intake of the diet containing Cry1A toxin. The significantly higher cadherin expression at the fourth instar facilitates the binding of Cry toxin with cadherin receptor in insect midgut, resulting in the oligomerisation of toxin and pore formation on the midgut membrane. The pore formation leads to cell lysis and eventually cause the death of the insect (Marroquin et al., 2000). The 
expression pattern was similar to the third instar of the susceptible strains of Diatraea saccharalis which was reported to have higher expression compared to its fifth instar (Yang et al., 2011). The significant lower expression of the cadherin gene from fifth to seventh instar in T. mundella from Tinbarap Estate suggests that the larvae may able to survive if it is exposed to the toxin only after its fourth instar stage. This data supports the pest management practice reported by Huan (2012) which suggested that the application of insecticide every two weeks over a three months period is necessary to control the infestation by breaking its life cycle.

The distinct cadherin expression pattern and mortality of $T$. mundella from the two sampling locations suggest that the resistant strain may have developed in the Sabaju Estate after exposed to an inconsistent schedule of insecticide application. Besides, this study displayed a remarkable change in cadherin expression pattern in the resistant strain of T. mundella when exposed to Cry1A toxin. The expression level dropped significantly after $2 \mathrm{hr}$ of toxin exposure. The trend may associate with the resistance mechanism of larvae against the toxin. The affinity of the cadherin receptor towards the toxin protein was reduced with a decrease in gene transcript level. The risk of the midgut pore formation was minimised and helps the insect to survive after toxin ingestion (Lee et al., 1995).

The current study demonstrated the connection of the cadherin gene expression of T. mundella with its resistance against Cry1A toxin. The data serves as a fundamental approach to understand the development of $B t$. insecticide resistance over time. Nevertheless, further study on more population of T. mundella is necessary to give a better understanding of the insecticide resistance development mechanism.

TABLE 7. QUANTIFICATION OF CADHERIN GENE EXPRESSION OF T. mundella FROM SABAJU AND TINBARAP ESTATES AFTER EXPOSED TO Bacillus thuringiensis (Bt.) INSECTICIDE

\begin{tabular}{|c|c|c|c|c|}
\hline \multirow{3}{*}{$\begin{array}{l}\text { Exposure } \\
\text { duration }\end{array}$} & \multicolumn{4}{|c|}{ Relatively transcript level ${ }^{*}$} \\
\hline & \multicolumn{2}{|c|}{ Sabaju } & \multicolumn{2}{|c|}{ Tinbarap } \\
\hline & Treatment & Control & Treatment & Control \\
\hline $0 \mathrm{hr}$ & $0.0016 \pm 0.0002 b$ & $0.0047 \pm 0.0009 b$ & $4.7682 \pm 0.7848 \mathrm{a}$ & $2.4513 \pm 0.3426 a$ \\
\hline $2 \mathrm{hr}$ & $0.3233 \pm 0.0669 a$ & $0.0055 \pm 0.0008 \mathrm{~b}$ & $1.0421 \pm 0.1567 \mathrm{~b}$ & $0.5739 \pm 0.0983 b$ \\
\hline $8 \mathrm{hr}$ & $0.1007 \pm 0.0170 \mathrm{~b}$ & $0.0034 \pm 0.0006 \mathrm{~b}$ & $1.9774 \pm 0.3769 \mathrm{~b}$ & $0.0793 \pm 0.0144 \mathrm{~b}$ \\
\hline $24 \mathrm{hr}$ & $0.0142 \pm 0.0019 \mathrm{~b}$ & $0.0066 \pm 0.0013 \mathrm{~b}$ & $0.5323 \pm 0.0704 \mathrm{~b}$ & $0.1796 \pm 0.0398 b$ \\
\hline $48 \mathrm{hr}$ & $0.0124 \pm 0.0018 \mathrm{~b}$ & $0.0147 \pm 0.0028 \mathrm{a}$ & $1.6938 \pm 0.2634 \mathrm{~b}$ & $0.7006 \pm 0.1328 b$ \\
\hline
\end{tabular}

Note: *Each value represents the mean \pm SE of three technical replicates and three biological replicates of insects tested in each parameter. The significant difference between the exposure durations was analysed using one-way ANOVA. Different letters denote a significant difference ( $\mathrm{P}<0.05$, Tukey's HSD test) in the expression levels between the exposure durations. The expression level of pupa from Tinbarap Estate was set at 1 .

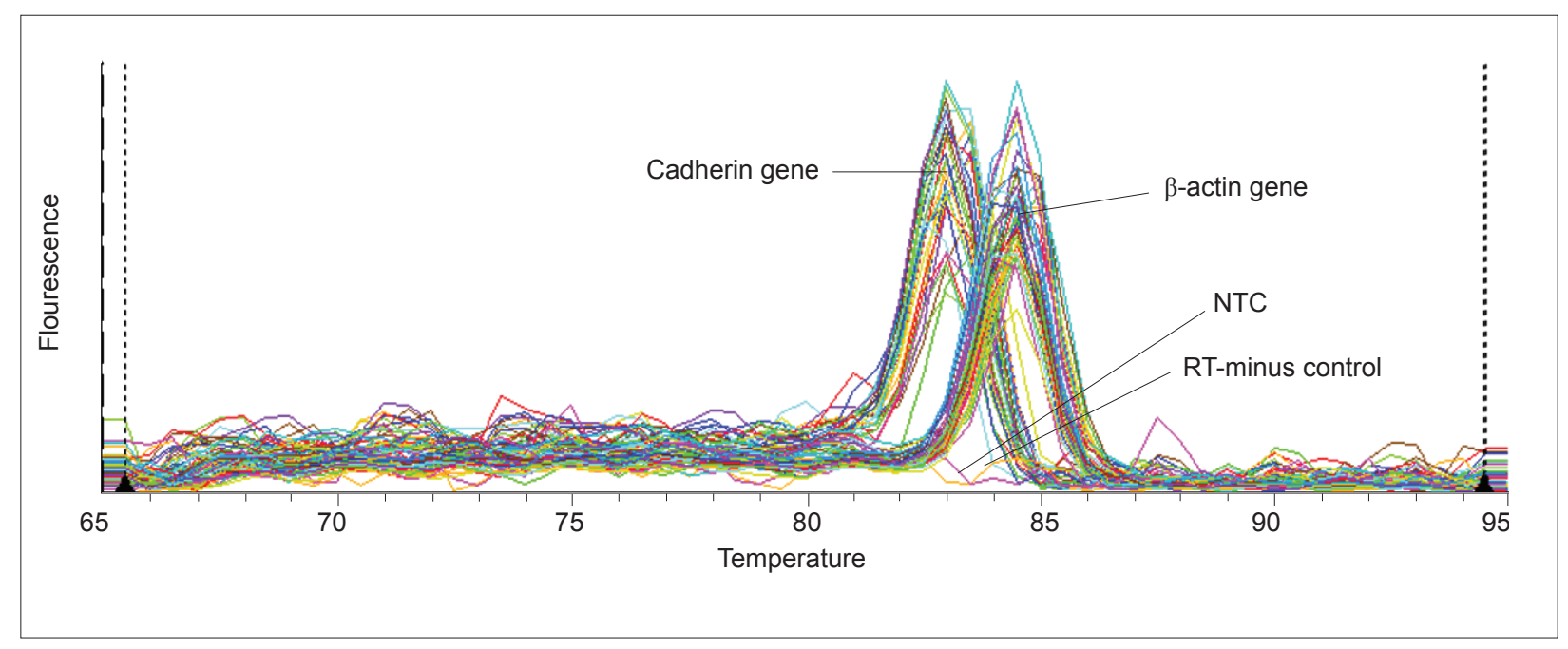

Figure 3. The melting curve of $\beta$-actin gene and cadherin gene by $q R T-P C R$. The melting curve of $\beta$-actin gene displayed a single peak at $84.5^{\circ} \mathrm{C}$ while cadherin gene displayed a single peak at $83.0^{\circ} \mathrm{C}$. The RT-minus control and no template control (NTC) show no melting curve peak. 


\section{CONCLUSION}

The findings of this study demonstrate the development of $T$. mundella resistance against Bt. insecticide at the molecular level. Lower expression of cadherin gene was identified in the resistance strain which contributes to the survival of insects under pest management practices. The data generated could assist in the enhancement of pest control strategies by serving as an indicator of the insect susceptibility against insecticide.

\section{ACKNOWLEDGEMENT}

The authors would like to thank Sarawak Oil Palms Berhad, Miri, Sarawak for support in the field work, and to UPMKB for the use of their facilities and technical supports. This research was funded by Grant Putra IPS GP-IPS / 2017/9541400.

\section{REFERENCES}

Alouw, J C; Morallo-Rejesus, B and Ocampo, V R (2005). Biology of the coconut spike moth, Tirathaba fructivora (Meyr.) (Lepidoptera: Pyralidae). Philipp. Entomol., 19(1): 84-93.

Ayra-Pardo, C; Raymond, B; Gulzar, A; RodríguezCabrera, L; Morán-Bertot, I; Crickmore, $\mathrm{N}$ and Wright, D J (2015). Novel genetic factors involved in resistance to Bacillus thuringiensis in Plutella xylostella. Insect Mol. Biol., 24(6): 589-600.

Bel, Y and Escriche, B (2006). Common genomic structure for the Lepidoptera cadherin-like genes. Gene, 381(1-2): 71-80.

Guo, Z; Kang, S; Chen, D; Wu, Q; Wang, S; Xie, W; Zhu, X; Baxter, S W; Zhou, X; Jurat-Fuentes, J L and Zhang, Y (2015). MAPK signalling pathway alters expression of midgut ALP and ABCC genes and causes resistance to Bacillus thuringiensis Cry1Ac toxin in diamondback moth. PLoS Genet., 11(4): 1005124.

Hervet, V A D; Laird, R A and Floate, K D (2016). A review of the McMorran Diet for rearing Lepidoptera species with addition of a further 39 species. J. Insect. Sci., 16(1): 362-364.

Huan, L K (2012). Integrated pest management of Tirathaba bunch moth on oil palm planted on peat. Planter, 88(1031): 97-104.

Jouzani, G S; Valijanian, E and Sharafi, R (2017). Bacillus thuringiensis: A successful insecticide with new environmental features and tidings. Appl. Microbiol. Biotechnol., 101(7): 2691-2711.

Kumar, S; Stecher, G and Tamura, K (2016). MEGA7: Molecular evolutionary genetics analysis version 7.0 for bigger datasets. Mol. Biol. Evol., 33(7): 1870-1874.

Lee, M K; Rajamohan, F; Gould, F and Dean, D H (1995). Resistance to Bacillus thuringiensis Cry1A delta-endotoxins in a laboratory-selected Heliothis virescens strain is related to receptor alteration. Appl. Microbiol. Biotechnol., 61(11): 3836-3842.

Marroquin, L D; Elyassnia, D; Griffitts, J S; Feitelson, J S and Aroian, R V (2000). Bacillus thuringiensis (Bt.) toxin susceptibility and isolation of resistance mutants in the nematode Caenorhabditis elegans. Genet., 155(4): 1693-1699.

Masijan, Z; Kamarudin, N; Moslim, R; Sintik, A G; Ahmad, S N H and Ali, S R A (2015). Bunch moth, Tirathaba rufivena (Lepidoptera: Pyralidae) infestation census from oil palm plantation on peat soil in Sarawak. Serangga, 20(1): 43-53.

Midboe, E G; Candas, M and Bulla, L A (2003). Expression of a midgut-specific cadherin BT-R1 during the development of Manduca sexta larva. Comp. Biochem. Physiol. B., 135(1): 125-137.

Morton, A C (1981). Rearing butterflies on artificial diets. J. Res. Lepid., 18: 221-227.

Pacheco, S; Gómez, I; Gill, S S; Bravo, A and Soberón, M (2009). Enhancement of insecticidal activity of Bacillus thuringiensis Cry1A toxins by fragments of a toxin-binding cadherin correlates with oligomer formation. Peptides, 30(3): 583-588.

Prasetyo, A E; Lopez, J A; Eldridge, J R; Zommick, D H and Susanto, A (2018). Long-term study of Bacillus thuringiensis application to control Tirathaba rufivena, along with the impact to Elaeidobius kamerunicus, insect biodiversity and oil palm productivity. J. Oil Palm Res., 30(1): 71-82.

Raymaekers, M; Smets, R; Maes, B and Cartuyvels, $R$ (2009). Checklist for optimization and validation of real-time PCR assays. J. Clin. Lab. Anal., 23(3): 145-151.

Ren, X L; Chen, R R; Zhang, Y; Ma, Y; Cui, J J; Han, Z J; Mu, L L and Li, G Q (2013). A Spodoptera exigua cadherin serves as a putative receptor for Bacillus thuringiensis Cry1Ca toxin and shows differential enhancement of Cry1Ca and Cry1Actoxicity. Appl. Environ. Microbiol., 79(18): 5576-5583. 
Saharul, A B; Zulkefli, M; Ramle, M; Mohamad, R S; Su, C M; Siaw, T C; Norman, K; Siti, R A A and Siti, N A (2017). Biological agents and insecticides to control bunch moth, Tirathaba rufivena in oil palm estates in Sarawak, Malaysia. J. Oil Palm Res., 29(3): 323-332.

Sanahuja, G; Banakar, R; Twyman, R M; Capell, T and Christou, P (2011). Bacillus thuringiensis: A century of research, development and commercial applications. Plant Biotechnol. J., 9(3): 283-300.

Su, C M (2019). Artificial diet for the laboratory rearing of Tirathaba mundella. Unpublished work. Universiti Putra Malaysia Bintulu Campus, Sarawak.

Su, C M; Bong, J C F and Ahmad, K (2016). Field ablation as cultural control for bunch moth Tirathaba mundella infestation in young mature oil palm. J. Oil Palm Res., 28(4): 463-470.

Su, C M; King, P J H; Tan, C Z K; Kwan, Y M; Zakry, F B A A; Bong, J C F and Ong, K H (2019). Life cycle of oil palm bunch moth, Tirathaba mundella walker Lepidoptera: Pyralidae reared under laboratory conditions on artificial diet. Int. J. Biol. Sci., 1(1): 9-10.

Tabashnik, B E (1994). Evolution of resistance to Bacillus thuringiensis. Annu. Rev. Entomol., 39: 47-79.

Tamura, K and Nei, M (1993). Estimation of the number of nucleotide substitutions in the control region of mitochondrial DNA in humans and chimpanzees. Mol. Biol. Evol., 10(3): 512-526.

Vachon, V; Laprade, R and Schwartz, J L (2012). Current models of the mode of action of Bacillus thuringiensis insecticidal crystal proteins: A critical review. J. Invertebr. Pathol., 111(1): 1-12.

Wang, L; Ma, Y; Wan, P; Liu, K; Xiao, Y; Wang, J; Cong, S; Xu, D; Wu, K; Fabrick, J A and Li, X (2018). Resistance to Bacillus thuringiensis linked with a cadherin transmembrane mutation affecting cellular trafficking in pink bollworm from China. Insect Biochem. Mol. Biol., 94: 28-35.
$\mathrm{Xu}, \mathrm{X} ; \mathrm{Yu}, \mathrm{L}$ and $\mathrm{Wu}, \mathrm{Y}$ (2005). Disruption of a cadherin gene associated with resistance to Cry1Ac $\delta$-endotoxin of Bacillus thuringiensis in Helicoverpa armigera. Society, 71(2): 948-954.

Yaakop, S and Shafariza, M A M (2015). The bunch moth of the Tirathaba species as a hidden pest on the peat soil of oil palm plantations: Implications of biological life cycles, the DNA barcoding approach and infestation pattern detection. Proc. of the $3^{\text {rd }}$ International Conference on Chemical, Agricultural and Medical Sciences (CAMS-2015). 10-11 December 2015. Singapore.

Yang, Y; Zhu, Y C; Ottea, J; Husseneder, C; Leonard, B R; Abel, C; Luttrell, R and Huang, F (2011). Down regulation of a gene for cadherin, but not alkaline phosphatase, associated with Cry1 Ab resistance in the sugarcane borer Diatraea saccharalis. PLoS ONE, 6(10): 1-12.

Yang, Z X; Wen, L Z; Wu, Q J; Wang, S L; Xu, B Y; Chang, X L; Zhu, G R and Zhang, Y J (2009). Effects of injecting cadherin gene dsRNA on growth and development in diamondback moth Plutella xylostella (Lep.: Plutellidae). J. Appl. Entomol., 133(2): 75-81.

Yang, Z X; Wu, Q J; Wang, S L; Chang, X L; Wang, J H; Guo, Z J; Lei, Y Y; Xu, B Y and Zhang, Y J (2012). Expression of cadherin, aminopeptidase $\mathrm{N}$ and alkaline phosphatase genes in Cry1Acsusceptible and Cry1Ac-resistant strains of Plutella xylostella (L.). J. Appl. Entomol., 136(7): 539-548.

Yu, T; Li, X; Coates, B S; Zhang, Q; Siegfried, B D and Zhou, X (2018). MicroRNA profiling between Bacillus thuringiensis Cry1Ab-susceptible and resistant European corn borer, Ostrinia nubilalis (Hübner). Insect Mol. Biol., 27(3): 279-294.

Zhang, Z; Teng, X; Ma, W and Li, F (2017). Knockdown of two Cadherin genes confers resistance to Cry2A and Cry1C in Chilo suppressalis. Sci. Rep., 7(1): 1-8. 